\title{
Induced Myopia among Readymade Garment (RGM) Workers
}

\author{
Anisur Rahman ${ }^{*}$, Sharah Rahman ${ }^{2}$, Jamsed Faridi1, Faria Tilat Toma ${ }^{3}$, \\ Ashfia Farhin Huq ${ }^{4}$, Ashraful Islam Khondokar ${ }^{5}$ \\ ${ }^{1}$ Department of Ophthalmology, Dhaka Medical College, Dhaka, Bangladesh \\ ${ }^{2}$ (Cornea \& Anterior Segment) Ispahani Islamia Eye Institute and Hospital, Dhaka, Bangladesh \\ ${ }^{3}$ Dhaka Medical College, Dhaka, Bangladesh \\ ${ }^{4}$ Bangladesh Eye Trust Hospital, Dhaka, Bangladesh \\ ${ }^{5}$ Department of Ophthalmology Dhaka Medical College and Hospital, Dhaka, Bangladesh \\ Email: *anjumk38dmc@gmail.com
}

How to cite this paper: Rahman, A., Rahman, S., Faridi, J., Toma, F.T., Huq, A.F. and Khondokar, A.I. (2021) Induced Myopia among Readymade Garment (RGM) Workers. Open Journal of Ophthalmology, 11, 91-98.

https://doi.org/10.4236/ojoph.2021.112007

Received: March 2, 2021

Accepted: May 5, 2021

Published: May 8, 2021

Copyright (c) 2021 by author(s) and Scientific Research Publishing Inc. This work is licensed under the Creative Commons Attribution International License (CC BY 4.0).

http://creativecommons.org/licenses/by/4.0/

\begin{abstract}
Background: To determine the induced refractive error among the readymade garment workers. Those who are working in the knitting section and those who are working other than the knitting and computer section. Methods: It was a prospective cross-sectional analytic study among 600 workers in 2 factories at Joydevpur, Gazipur, Bangladesh on January 2020. Group: A comprises 300 workers who were working at knitting section for a minimum of six hours a day and 5 days a week. Group: B comprises another 300 workers who were appointed for loading-unloading, care-taker, driver and security guard also. Prevalence of refractive error in two groups was compared. Results: The mean age of participants in group: A was $26.61 \pm 4.99$ (CI 95\%, $26.04 \pm 27.18)$ and in group: B was $28.51 \pm 5.69$ (95\% CI $27.86 \pm 29.15)$. Prevalence of refractive error between two groups was 52 and 28.3 respectively. The chi-square statistic is 44.9775 . The $\mathrm{p}$-value is $<0.00001$. Significant at $\mathrm{p}<$ 0.05. Strong positive correlation shows in Pearson's correlation between time duration of knitting and refractive error ( $\mathrm{R}$ is: 0.7619$)$. Visual acuity between two groups chi-square statistic is 33.1866 . The $\mathrm{p}$-value is $<0.00001$. Significant at $\mathrm{p}<0.05$. Conclusion: Knitting workers at readymade garment (RGM) are more prone to develop late onset myopia than other workers in the same premises.
\end{abstract}

\section{Keywords}

Myopia, Readymade Garment (RGM), Near-Work, Late Onset Myopia, Visual Acuity 


\section{Introduction}

Bangladesh is the world's second-largest Readymade Garment (RMG) exporter with $81 \%$ of its exports coming from the RMG sector. There are about 4500 factories in Bangladesh with 3.6 million workers [1] [2]. Before 24, April 2013 disaster of Rana Plaza, Savar, Dhaka the working environment of the garment factory was not monitored. In June 2013, immediate aftermath of the Rana Plaza, an implementation plan was agreed to lead to the incorporation of the Bangladesh Accord Foundation in the Netherlands in October 2013. It is an example of project-oriented multistakeholder governance [3]. Workers are now able to access health facilities. Most of their jobs like knitting, sewing, matching colors are vision dependent. However, they tend to hide their ocular problems for fear of termination from the job.

Myopia is an emerging public issue in South Asia. The prevalence of school myopia is increasing progressively day by day. In recent decade it is about $80 \%$ $90 \%$ at school level [4]. It was assumed that in 2010, prevalence of myopia was 28 but in 2050 prevalence will be 50 [5] [6]. Various studies showed that myopia is directly proportional to near work [7] [8] [9]. But most of the study was conducted among school children. There is lacking sufficient data regarding onset of myopia after 18 years as these age groups are usually neglected and common myth that progression of myopia is usually halted after 18 to 20 years. In the last few decades expansion of garments factory occurs mostly in developing countries due to cheap labor costs.

Because of the long hours of work and pressure from management, many factory workers were suffering from stress, fatigue and eye problems [10] [11] [12]. In a recent study, it was found that the eyesight of the workers become so poor that many have to leave their jobs by the age of 25 . In Singapore, $17.2 \%$ of those who worked in electronic assembly obtained glasses, compared with $2.5 \%$ of those who had not worked there. In Malaysia, 7.3\% of those formerly in electronic assembly industries had glasses, compared with $2.9 \%$ of those not working there [13]

The US-based organization "Vision Spring" conducted a trial on 66,000 workers at 16 garments factories in Dhaka, Gazipur and Chittagong recently and they observed about $27 \%$ of workers are suffering from vision problem [14]. The vision problem will get worse with the course of time if it is untreated. When untrained personnel become trained and develop expertise, they became visually unfit and this is the worst part of an apparel factory.

Now, there is a term which is called Near Work-Induced Transient Myopia (NITM). Several studies reported that NITM has a greater influence on Late-onset Myopes (LOM) than Early-onset Myopes (EOM) or Emmetropes (EMM) [15].

\section{Materials \& Method}

It was a cross-sectional analytic study conducted at two garments factories at Joydevpur, Gazipur, Bangladesh on January 2020. Workers who met the inclu- 
sion criteria were enrolled for the study. The inclusion criteria were age of the subject between 18 - 40 years, who were working minimum six-hour near work, who have minimum knowledge to read Bangla (Mother language for Bangladeshi), who are working more than one year. As a preliminary eye checkup was mandatory for entrance into the job, workers who had no prior ocular morbidity like refractive error (Visual acuity $6 / 6$ for distance and N6 for near) when joining the job was included in this study. Exclusion criteria includes, those who were using spectacle before joining the factory, any ocular co-morbidity, pregnant lady and those who are not interested to take part in this survey.

Among the 7554 workers of the two factories, 600 workers were included in our study. Non-probability purposive sampling was used. We divided our population in two groups. Group A comprises 300 workers who worked in the knitting and computer section for minimum 6 hours in a day and 5 days in a week. Group B comprises 300 workers who were in the factory but not involved in any kind of near work. They were appointed as workers for loading and unloading of products, care-taker, driver, mechanic, electrician and security guard.

We prepare a questionnaire in Bengali and it was filled up by each candidate. It contained general information about the subject without any name or identification number. The points mentioned were age of the subject, how long he or she is working in this factory, whether facing any visual problem, any symptoms like headache, eyestrain, blurry vision during his/her work. All the symptoms wrote positive if it was present 1 day in a week for a minimum of one hour without pain-killer.

Visual acuity was recoded with Snellen chart, and converted in to LogMAR (Logarithm of the Minimum Angle of Resolution). Workers having visual acuity less than 6/6 were examined by auto-refractometer (TOPCON Type Auto Refractometer Model RM-8800Color liquid crystal display screen). When entering into the job their visual acuity for distance and near and Color vision was tested. These 600 subjects had visual acuity of 6/6 for distance and N6 for near without any aid at the beginning of the job.

The collected data were analyzed by SPSS version 22. Categorical data was analyzed by Chi-squared or Fisher Exact test. Continuous data which was descriptive expressed with Mean, SD and confidence interval (95\% confidence interval). Relation between the refractive errors with time duration was analyzed by Pearson's correlation test.

\section{Results}

Table 1 shows, in knitting section more are female 78.67\% (Group: A). Those who are not involve in near work male are more $70 \%$ (Group: B).

Table 2 shows most are 23 - 27 years old in knitting section (42\%) and $38-40$ years are least (4.66\%). Those are not involved in knitting section most are 28 32 years old (32.67\%) and 38 - 40 years is least (6.33\%). That is Group: A, mean \pm SD. $26.61 \pm 4.99$ (CI 95\%, $26.04 \pm 27.18)$. In group: B, $28.51 \pm 5.69$ (95\% CI 
$27.86 \pm 29.15)$.

Table 3 shows in group A refractive error increases with duration of service more in knitting section than non-knitting section and the chi-square statistic is 44.9775. The $\mathrm{p}$-value is $<0.00001$. Significant at $\mathrm{p}<0.05$.

Table 4 shows visual acuity reduced more among the worker of Knitting section than the non-knitting section. The chi-square statistic is 33.1866. The p-value is $<0.00001$. Significant at $\mathrm{p}<0.05$.

Table 5 shows symptoms among the workers and we quantify three symptoms headache, eye-strain and blurry vision. It shows all the symptoms are more Table 1. Gender in both groups.

\begin{tabular}{|c|c|c|c|c|}
\hline \multirow[b]{2}{*}{ Male } & \multicolumn{2}{|c|}{ Group: A (n: 300) } & \multicolumn{2}{|c|}{ Group: B (n: 300) } \\
\hline & 64 & $21.33 \%$ & 210 & $70 \%$ \\
\hline Female & 236 & $78.67 \%$ & 90 & $30 \%$ \\
\hline Total & 300 & $100 \%$ & 300 & $100 \%$ \\
\hline
\end{tabular}

Table 2. Percentage of worker according to age group.

\begin{tabular}{|c|c|c|c|c|c|}
\hline \multirow{2}{*}{ Categories } & \multicolumn{2}{|c|}{ Group: $A(n=300)$} & \multicolumn{2}{|c|}{ Group: $B(n=300)$} & \\
\hline & Respond & $\%$ & Respond & $\%$ & \\
\hline 18 - 22 Yrs. & 62 & $20.67 \%$ & 56 & $18.67 \%$ & \multirow{6}{*}{$\begin{array}{c}\text { Group: A, mean } \pm \text { SD. } \\
26.61 \pm 4.99 \text { (CI } 95 \%, 26.04 \\
\pm 27.18) . \text { In group: } B, 28.51 \\
\pm 5.69(95 \% \text { CI, } 27.86 \pm \\
29.15)\end{array}$} \\
\hline 23 - 27 Yrs. & 126 & $42.0 \%$ & 66 & $22.0 \%$ & \\
\hline $28-32$ Yrs. & 72 & $24 \%$ & 98 & $32.67 \%$ & \\
\hline 33 - 37 Yrs. & 26 & $8.67 \%$ & 61 & $20.33 \%$ & \\
\hline \multirow[t]{2}{*}{$38-40$ Yrs. } & 14 & $4.66 \%$ & 19 & $6.33 \%$ & \\
\hline & 300 & $100 \%$ & 300 & $100 \%$ & \\
\hline
\end{tabular}

Table 3. Duration of work (in year) at RGM and newly develop refractive error.

\begin{tabular}{|c|c|c|c|c|c|}
\hline & \multicolumn{2}{|c|}{ Group: A (n: 300) } & \multicolumn{2}{|c|}{ Group: B (n: 300) } & \\
\hline & $\begin{array}{c}\text { Number of } \\
\text { workers }\end{array}$ & $\begin{array}{c}\text { Number of } \\
\text { workers with } \mathrm{RE}\end{array}$ & $\begin{array}{c}\text { Number of } \\
\text { workers }\end{array}$ & $\begin{array}{c}\text { Number of } \\
\text { workers with } \mathrm{RE}\end{array}$ & \\
\hline$\leq 2-\mathrm{yr}$ & $27(9 \%)$ & $10(3.33 \%)$ & $25(8.33 \%)$ & $5(1.67 \%)$ & \\
\hline $3-y r$ & $36(12 \%)$ & $14(4.67 \%)$ & $31(10.33 \%)$ & $6(2 \%)$ & \\
\hline $4-y \mathrm{r}$ & $47(15.67 \%)$ & $20(6.67 \%)$ & $52(17.33 \%)$ & $11(3.67)$ & The chi-square \\
\hline $5-y r$ & $48(16 \%)$ & $25(8.33 \%)$ & $45(15 \%)$ & $12(4 \%)$ & $\begin{array}{c}\text { statistic is } 44.9775 \text {. } \\
\text { The p-value is }\end{array}$ \\
\hline $6-y r$ & $37(12.33 \%)$ & $22(7.33 \%)$ & $41(13.67 \%)$ & $12(4 \%)$ & $<0.00001$ \\
\hline $7-y r$ & $35(11.67 \%)$ & $21(7 \%)$ & $30(10 \%)$ & $9(3 \%)$ & $\begin{array}{c}\text { Significant at } \mathrm{p}< \\
0.05 .\end{array}$ \\
\hline $8-y r$ & $23(7.67 \%)$ & $14(4.67 \%)$ & $27(9 \%)$ & $8(2.67)$ & RE: Refractive error \\
\hline $9-y r$ & $22(7.33 \%)$ & $13(4.33 \%)$ & $30(10 \%)$ & $6(2 \%)$ & \\
\hline$>10-y r$ & $25(8.33 \%)$ & $17(5.67 \%)$ & $196.33 \%)$ & $7(2.33 \%)$ & \\
\hline Total & $300(100 \%)$ & $156(52 \%)$ & $300(100 \%)$ & $76(28.34)$ & \\
\hline
\end{tabular}


Table 4. Visual acuity of the worker.

\begin{tabular}{|c|c|c|c|c|c|}
\hline \multirow{2}{*}{ Categories } & \multicolumn{2}{|c|}{ Group: $A(n=300)$} & \multicolumn{2}{|c|}{ Group: $B(n=300)$} & \\
\hline & Respond & $\%$ & & $\%$ & \\
\hline $6 / 6(0)$ & 144 & $48.0 \%$ & 224 & $70.33 \%$ & \multirow{8}{*}{$\begin{array}{c}\text { The chi-square statistic } \\
\text { is } 33.1866 . \text { The p-value is } \\
<0.00001 . \text { Significant at } \\
\text { p }<0.05 .\end{array}$} \\
\hline $6 / 9(0.2)$ & 61 & $20.33 \%$ & 37 & $12.33 \%$ & \\
\hline $6 / 12(0.3)$ & 32 & $10.67 \%$ & 19 & $6.33 \%$ & \\
\hline $6 / 18(0.5)$ & 24 & $8 \%$ & 10 & $3.33 \%$ & \\
\hline $6 / 24(0.6)$ & 15 & $5 \%$ & 4 & $1.33 \%$ & \\
\hline $6 / 36(0.8)$ & 14 & $4.67 \%$ & 4 & $1.2 \%$ & \\
\hline \multirow[t]{2}{*}{$6 / 60(1)$} & 10 & $3.33 \%$ & 2 & $0.67 \%$ & \\
\hline & 300 & $100 \%$ & 300 & $100 \%$ & \\
\hline
\end{tabular}

Table 5. Shows different symptoms between the two groups.

\begin{tabular}{|c|c|c|c|}
\hline Symptoms & Group: A & Group: B & Results \\
\hline Headache & $224(74.67 \%)$ & $46(15.33 \%)$ & $\begin{array}{l}\text { The chi-square statistic is } 213.3603 \text {. The } \\
\text { p-value is }<0.00001 \text {. Significant at } \mathrm{p}<0.05\end{array}$ \\
\hline Eye-strain & $132(44.0 \%)$ & $19(6.33 \%)$ & $\begin{array}{l}\text { The chi-square statistic is } 113.0017 \text {. The } \\
\text { p-value is }<0.00001 \text {. Significant at } p<0.05 \text {. }\end{array}$ \\
\hline Blurry vision & $169(56.33 \%)$ & $34(11.33 \%)$ & $\begin{array}{l}\text { The chi-square statistic is } 135.6851 \text {. The } \\
\text { p-value is }<0.00001 \text {. Significant at } p<0.05 \text {. }\end{array}$ \\
\hline
\end{tabular}

frequent among the worker of knitting and computer section than the others.

\section{Discussion}

Bangladesh had a golden history of Jute industry globally, but in virtue of time plastic replaced the Jute [16]. As millions of people left jobless, due to low cost labor and availability of workers, Bangladesh emerges as a garments friendly nation.

Due to the long hours of continuous working, especially near workings, workers of garment factories are suffering from vision-related problems nowadays. There are many articles showing that myopia can start at any age [16]. Although myopia in early life is familial, sometimes environmental. However, late onset myopia (after 18 to 21 years) is due to excessive near work for a longer period of time. In our study, we attempt to find out how many people in a garment factory, who are involved in knitting section have developed a visual problem in comparison to those who are in the same premises working but not involved in near works.

In knitting section female workers are more. From Table 1, among the 300 workers in group: A, 236 (78.67\%) working in knitting section are female, whereas male is only $64(21.33 \%)$. In group: $\mathrm{B}$, where the duty of the worker is not near vision dependent, 210 (70\%) are male and 90 (30\%) are female.

From Table 2, workers in the knitting section are between the age group of 23 - 27 years, which is $126(42 \%)$ whereas workers outside the knitting section are 
between the age group of 28 - 32 years, which is 98 (32.67\%). The mean age and standard deviation in group: A is $26.61 \pm 4.99$ (CI 95\%, $26.04 \pm 27.18$ ) and group $B$ is $28.51 \pm 5.69(95 \%$ CI $27.86 \pm 29.15)$ respectively.

From Table 3 , about induced-myopia, knitting workers are significantly differ from the non-knitting workers group (The $\mathrm{p}$-value is $<0.00001$. Significant at $\mathrm{p}<$ $0.05)$. Along the whole working period prevalence between the two groups are 52 and 28 respectively.

In Figure 1 it also shows that the refractive error increases with time duration and Pearson's correlation ( $\mathrm{R}$ is: 0.7619 ) strongly suggest it is directly proportional. According to Lin Z, et al. [17] the progression of myopia at late teen is directly proportional to near-work and garments worker who are at knitting section is prone to develop more myopia.

In Table 4, we see that there are $144(48 \%)$ have visual acuity is $6 / 6(\log 0)$ and rest 156 (52\%) have visual acuity below 6/6. At the same time in Group: B shows that out of three hundred, 224 (70.33\%) have visual acuity 6/6, and rest 76 (29.67\%) have vision below 6/6. In Chi-squared test with one degree of freedom $\mathrm{x}^{2}$ value is 27.939 the two-tailed $\mathrm{P}$ value is less than 0.0001 which is considered to be extremely statistically significant.

From Table 5, according to different symptoms headache is the most common (The chi-square statistic is 213.3603 . The $\mathrm{p}$-value is $<0.00001$. Significant at $\mathrm{p}<0.05$ ). Second common is blurry vision (The chi-square statistic is 135.6851 . The $\mathrm{p}$-value is $<0.00001$. Significant at $\mathrm{p}<0.05$ ) are highly significant among the knitting workers. Eye-strain (The chi-square statistic is 113.0017. The p-value is $<0.00001$. Significant at $\mathrm{p}<0.05)$. Different studies show that the female workers in the garment sector suffer from the diseases like problems in bones, skin, eye stain, visual problem, headache [18] [19].

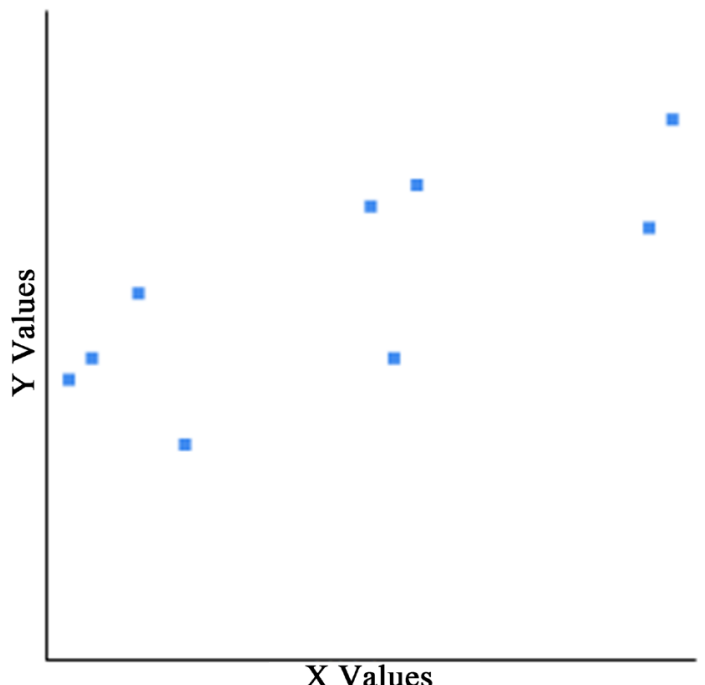

Figure 1. Pearson's correlation shows strong positive correlation between time duration of knitting and refractive error ( $\mathrm{R}$ is: 0.7619 . The P-Value is $<0.00001$. The result is significant at $\mathrm{p}<0.05)$. 
From this study we can come to a conclusion that Knitting workers at readymade garment (RGM) are more prone to develop induced-myopia and other eye related problems. As the economy of the Bangladesh is vastly dependent on this garment sector, this induced myopia will reduce the working capability and work performance of the workers. The policy makers should include the regular eye health checkup for all the workers. The appropriate management of the refractive error can be easily corrected by a cost effective spectacle prescription. Regular break during work can reduce the eye strain, fatigue and headache etc. If needed, medicine can be prescribed.

However, still we can say that the policy makers and other concerned bodies should take necessary actions to ensure good eye health of the garment workers. It will help workers to be more productive and their contribution to the country will be enhanced.

\section{Conclusion}

Sound health is the prerequisite for a successful industry, when a worker became experienced in his/her field but can't give his/her support to the industry it's a great loss for the industry as well as the country. In this article we have seen that dimness of vision, eye strain, headache becomes more among the knitting and computer section and the induced myopia for excessive near work so it is time for every RGM to think about the regular eye check-up and break within the working hour. Ironically, better health conditions for the RMG workers would benefit the factory owners and the economy, in the long term.

\section{Acknowledgements}

We hereby acknowledge Green Eye Hospital Ltd Dhanmondi, Dhaka, Bangladesh for their instrumental (Auto-refractometer, view-box, pen torch, etc.) support to examine the workers. We also acknowledge Staff nurse of Department of Ophthalmology Dhaka Medical College to give us support with man power who worked with us during the study period. We also give our thanks to our friend Mr. Khandker Jamil Uddin Managing Director of Shanta Garments.

\section{Conflicts of Interest}

The authors declare no conflicts of interest regarding the publication of this paper.

\section{References}

[1] Stitch Diary (2020) What Makes Bangladesh-A Hub of Garment Manufacturing? https://medium.com/@stitchdiary/what-makes-bangladesh-a-hub-of-garment-man ufacturing-

[2] The Asia Foundation (2020) Bangladesh's Garment Workers. https://asiafoundation.org/2012/09/12/bangladeshs-garment-workers/

[3] Wikipedia (2020) Accord on Fire and Building Safety in Bangladesh. https://en.wikipedia.org/wiki/Accord_on_Fire_and_Building_Safety_in_Bangladesh 
[4] Morgan, G., Matsui, K.O. and Saw, S.M. (2012) Myopia. The Lancet, 379, 1739-1748. https://doi.org/10.1016/S0140-6736(12)60272-4

[5] Sankaridurg, P. (2017) Contact Lenses to Slow Progression of Myopia. Clinical and Experimental Optometry, 100, 432-437. https://doi.org/10.1111/cxo.12584

[6] Cumberland, P.M., Bountziouka, V. and Rahi, J.S. (2018) Impact of Varying the Definition of Myopia on Estimates of Prevalence and Associations with Risk Factors: Time for an Approach That Serves Research, Practice and Policy. British Journal of Ophthalmology, 102, 1407-1412. https://doi.org/10.1136/bjophthalmol-2017-311557

[7] Mutti, D.O., Mitchell, G.L., Moeschberger, M.L., Jones, L.A. and Zadnik, K. (2002) Parental Myopia, Near Work, School Achievement, and Children's Refractive Error. Investigative Ophthalmology \& Visual Science, 43, 3633-3640.

[8] Saw, S.-M., Chua, W.-H., Hong, C.-Y., Wu, H.-M., Chan, W.-Y., Chia, K.-S., et al. (2002) Near Work in Early-Onset Myopia. Investigative Ophthalmology \& Visual Science, 43, 332-339.

[9] Ip, J.M., Saw, S.-M., Rose, K.A., Morgan, I.G., Kifley, A., Wang, J.J., et al. (2008) Role of Near Work in Myopia: Findings in a Sample of Australian School Children. Investigative Ophthalmology \& Visual Science, 49, 2903-2910. https://doi.org/10.1167/iovs.07-0804

[10] Rachael, G. (1978) Women's Place in the Integrated Circuit. Pacific Research, 9, $2-17$.

[11] Oyelaran, O.A., Tudunwada, Y.Y., Abidoye, J.K. and Sanusi, O.M. (2016) A Study on Impact of Work Stress among Mat Factory Workers in Kano-Nigeria in 2015. Iranian Journal of Health, Safety \& Environment, 4, 746-751.

[12] Lillian, W. (1982) Workers I Needs and Employer-Organized Labor Welfare Programs: A Case Study. University Sains Malaysia, Malaysia.

[13] Lim, K.H., Wan, W.P. and Chew, P.K. (1972) Survey of Visual Status of Factory Employees in Electronics Industry in Singapore. Singapore Medical Journal, 13, 284-290.

[14] Lee, D.C., Lee, S.Y. and Kim, Y.C. (2018) An Epidemiological Study of the Risk Factors Associated with Myopia in Young Adult Men in Korea. Scientific Report, 8, Article No. 511. https://doi.org/10.1038/s41598-017-18926-2

[15] Chan, V.F., Naidoo, J., Chinanayi, F.S. and Naidoo, K.S. (2017) Near Vision Correction and Quality of Life among Textile Factory Workers in Durban. African Vision and Eye Health, 76, a384. https://doi.org/10.4102/aveh.v76i1.384

[16] Myopia (Nearsightedness) (2021) American Optometric Association. https://www.aoa.org/healthy-eyes/eye-and-vision-conditions/myopia

[17] Lin, Z., et al. (2020) The Association between Near Work-Induced Transient Myopia and Progression of Refractive Error: A 3-Year Cohort Report from Beijing Myopia Progression Study. Journal of Optometry, 14, 44-49. https://doi.org/10.1016/j.optom.2020.05.004

[18] Ahmed, S. and Raihan, M. (2014) Health Status of the Female Workers in the Garment Sector of Bangladesh. Journal of the Faculty of Economics and Administrative Sciences, 4, 43-58.

[19] Khan, N.R., Dipti, T.R., Ferdousi, S.K., Hossain, M.Z., Ferdousi, S., Sony, S.A., et al. (2015) Occupational Health Hazards among Workers of Garment Factories in Dhaka City. Journal of Dhaka Medical College, 24, 36-43. https://doi.org/10.3329/jdmc.v24i1.29560 